我が国の電力システムの現状・将来展望と超電導技術への期待

一2050 年カーボンニュートラルへ向けての取組と超電導技術の役割—

\author{
秋田 調 ${ }^{*} 1, \dagger$
}

\title{
Present Status of Electric Power System in Japan and Expectations for the Applied Superconducting Technologies \\ - Preparation for a Carbon-Neutral Society by 2050 and the Role of Superconducting Technologies -
}

\author{
Shirabe AKITA $^{* 1, \dagger}$
}

\begin{abstract}
Synopsis: This article describes the power system reformation in Japan, and the future perspectives to realize a carbon-neutral society by 2050 in the viewpoint of electric power system. Further, some possibilities to apply superconducting power technologies to support a carbon-neutral society have been investigated as well.
\end{abstract}

Keywords: power system reform, carbon neutral, superconducting power application, SMES

\section{1. はじめに}

我が国の電力システムは現在大きな変革の途上にあり、 引き続き 2050 年のカーボンニュートラル社会の実現に向 けて、これまで経験したことがない大きな技術革新を求め られている。

これまでの我が国の電気事業は Fig. 1 の左側に示される 通り、発電、送電、配電から小売りまですべての機能を担 う一般電気事業者が電力の安定供給に関するすべての責務 を担っていた 1)。2013 年から (1)安定供給の確保、(2)電気料 金の最大限の抑制、(3)需要家の選択肢や事業者の事業機会 の拡大、を目的として開始された電力システム改革は(1)広 域的な送電線運用の拡大、(2)小売りの全面自由化、(3)法的 分離による送配電部門の中立性の一層の確保、を 3 つの大 きな柱として実施され、2020 年 4 月の送配電部門の法的分 離により完結した。現時点の電力システムの姿は Fig. 1 の 右側に記載の通りであるが、これまで垂直的に統合され一

Received April 30, 2021

${ }^{*} 1$ 一般財団法人 電力中央研究所

广100-8126 東京都千代田区大手町 1-6-1

CRIEPI, 1-6-1 Otemachi, Chiyoda-ku, Tokyo 100-8126, Japan

${ }^{\dagger}$ E-mail: akita@criepi.denken.or.jp

DOI: $10.2221 /$ jesj. 56.243
体であった電気事業を発電会社、小売会社および送配電事 業者に分割し、様々な市場でつなげる姿となった。電力の 価值を取引する市場は「卸電力市場」「小売り電力市場」 以外にも「ベースロード市場」「受給調整市場」「容量市場」 「非化石価值取引市場」がすでに開設されている。

これらの市場はこれまで一体として運用されてきた電力 の $\mathrm{kWh}$ 価值、 $\mathrm{kW}$ 価值、 $\Delta \mathrm{kW}$ 価值、低炭素価值などを切 り出して取引するものであり、全体が調和して機能するか に関してはまだ試行錯誤的なところが見られる。2021 年 1月には LNG 燃料の不足により卸電力市場での前日取引価 格が、一時、通常の小売価格を大幅に上回る 250 円/kWh を越え大きなニュースとなった。なお、小売会社は 30 分 単位で販売する電力に等しい発電電力を確保する義務があ り、市場取引に加え相対でも発電電力を購入している。現 時点では一般社団法人日本卸電力取引所（JEPX：Japan Electric Power Exchange) を通しての電力取引は電力需要 の 4 割程度である。

一方、菅義偉首相は 2020 年 10 月 26 日に開会した臨時 国会の所信表明演説で 2050 年にカーボンニュートラルを 目指すことを表明した。これまでのエネルギー基本政策は 2030 年までに 2013 年と比較して温暖化効果ガス排出量を $26 \%$ 削減し、更に 2050 年には 80 \%削減を目指すとの内容 であったが、これを大きく上回る目標值の設定である。さ 


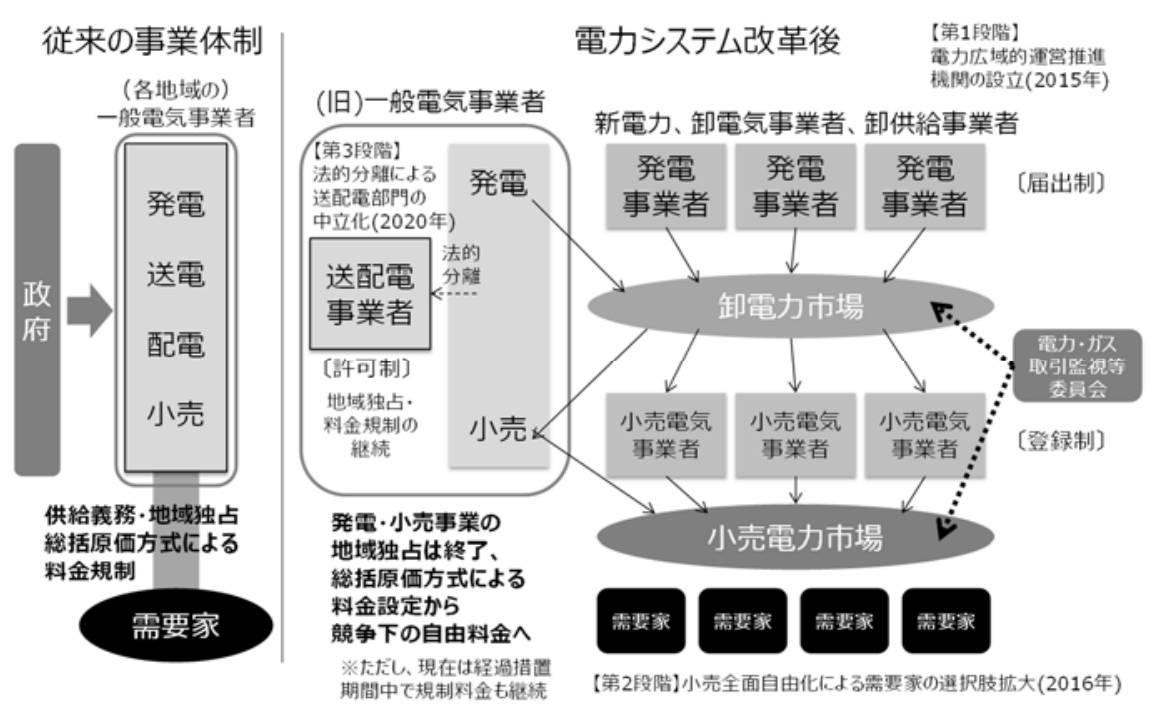

図1 電カシステム改革と電力市場

服部徹：「電力システム改革における新市場創設の意義と課題」電力経済研究 No. 66, p. 3 (2019.3)

Fig. 1 Organization structure before and after the power system reform.

らに、2021 年 4 月 22 日に開催された政府の地球温暖化対 策推進本部で、2030 年度の温室効果ガス削減目標を 2013年度比で $46 \%$ とすることを表明した。ただし、エネ ルギー基本計画の見直しは今後進められる予定であり、電 カシステムとしての削減目標は未検討である。

電力中央研究所では 2050 年 $80 \%$ 削減を可能とする電力 システムの想定を行ったが 2)、原子力発電所を 2,882 万 $\mathrm{kW}$ 運転したうえで、太陽光発電を 35,590 万 $\mathrm{kW}$ 、洋上を 含む風力発電を 7,500 万 $\mathrm{kW}$ 導入し、太陽光発電の出力抑 制を行わないためには 21,568 万 $\mathrm{kW}$ の蓄電池を導入する 必要があるとの試算結果となった。このような電源構成で あれば総発電に占める同期発電機の割合を $50 \%$ 以上に保 つことが可能であることは確認できたが、地理的に偏在す る可能性が高い太陽光発電および風力発電からの電力をど のように需要地まで輸送するかに関してはまだ未検討であ る。なお、他産業からの $\mathrm{CO}_{2}$ 排出量では製鉄、セメント製 造など削減が難しい技術も多いため、電力システムからの 排出削減量は $88 \%$ となっている。

2050 年カーボンニュートラルを実現できる社会像およ び電力システムの姿はまだ明確化されていないが、これま での技術の延長では実現が難しいことは確実であり、超電 導技術を含むあらゆる技術を総動員する必要がある。

\section{2050 年カーボンニュートラルに向けた検討状況}

菅首相の表明を受け、政府では内閣官房長官を議長とす る「成長戦略会議」を設置し検討を進めている。この中で 経済産業省では「2050 年カーボンニュートラルに伴うグ リーン成長戦略」の策定を進めており、2021 年 4 月 12 日
に開催された第 9 回会議で中間報告をしているが、まだ総 論の検討に留まっており「本年に入って、実際に、研究開 発方針や経営方針の転換、ゲームチェンジが始まっている。 この流れを加速す心゙く、更なる具体化を行い、2030 年の 排出削減を視野に入れた、2050 年・カーボンニュートラ ル社会の実現可能性を、更に高める。」と報告されている。 ただし NEDOに造成する 2 兆円の「グリーンイノベーショ ン基金」に関しては 2021 年 3 月 12 日に基本方針を策定し た 3)。2020 年時点の重点分野は、(1)洋上風力産業、(2)燃 料アンモニア産業、(3)水素産業、(4)原子力産業、(5)自動 車・蓄電池産業、6 半導体 ・情報通信産業、(7)船舶産業、 (8)物流・人流・インフラ土木産業、(9)食料・農林水産業、 (10)航空機産業、(11)カーボンリサイクル産業、(12) 住宅・建 築物産業／次世代型太陽光産業、(13)資源循環関連産業、(14) ライフスタイル関連産業の 14 分野としている。さらに NEDO ではグリーンイノベーション基金事業の詳細検討を 進めており、既にいくつかの公募事業の予告を行っている ${ }^{4)}$ ただし NEDO は、法律により専ら原子力を対象とする研 究開発を実施・補助することはできないとしているため、 エネルギー関係としては(1)洋上風力産業、(2)燃料アンモニ ア産業、(3)水素産業の 3 課題となる。一方、エネルギーシ ステムさらには電力システムとしてどのようにカーボン ニュートラルを実現するかに関しては全く先が見えない状 況である。電力システムに対しては他産業からの排出を相 殺するために、例えばバイオマス発電から排出される $\mathrm{CO}_{2}$ に対して CCS (Carbon dioxide Capture and Storage) を組み 合わせること等によるマイナスの排出原単位を求められる 可能性もある。 


\section{3. カーボンニュートラルを目指す電カシステム運用}

カーボンニュートラルを実現する電力システムにおいて は太陽光、風力などの再生可能エネルギーからの発電の割 合をできる限り高める必要がある。Fig. 2 に 2018 年 10 月 21 日の九州電力における発電の状況を示す5)。横軸は当日 の 0 時から 24 時を示している。

Fig. 2 に示すように 12 時 30 分の時点では太陽光発電は 551 万 $\mathrm{kW}$ の発電が可能であるが、九州電力管内の揚水発 電所で揚水のために 184 万 $\mathrm{kW}$ を消費し、中国電力に向け て関門海峡を渡る関門連系送電線により 194 万 $\mathrm{kW}$ を送電 しても使いきれないため、太陽光発電からの出力を 93 万 $\mathrm{kW}$ 抑制している。一見、火力発電の出力を更に絞り込め ば太陽光発電からの電力をすべて利用できるように見える が、石炭などの火力発電ではボイラーを安定に燃焼させる ための最小出力の制約がありこれ以上出力を下げることは 困難である。ボイラーの火を消し運転を停止すれば出力は 下がるが太陽光発電の出力が低下寸る夕方に再起動しても 発電開始までに時間を要するため間に合わない。なお、短 時間に起動停止が可能な LNG コンバインド火力発電所で は朝に起動をするが、昼間は運転を停止し夕方に再起動す る運転が既に行われている。また、昼間に揚水された水は 夕方から夜にかけて発電に使われ、翌日昼間の揚水運転に 備えている。

2050 年に実現を目指すカーボンニュートラル社会では、 Fig. 2 のベース部分となっている、水力、風力、原子力、 地熱発電の割合を高めるとともに調整電源となっている火 力発電の燃料を、バイオマス、水素、アンモニアなど二酸 化炭素を排出しない燃料に転換する必要がある。さらに、 現在は揚水発電が担っている日間の発電と需要のアンバラ ンス分の調整に電池、SMES などの新しい電力貯蔵方式を

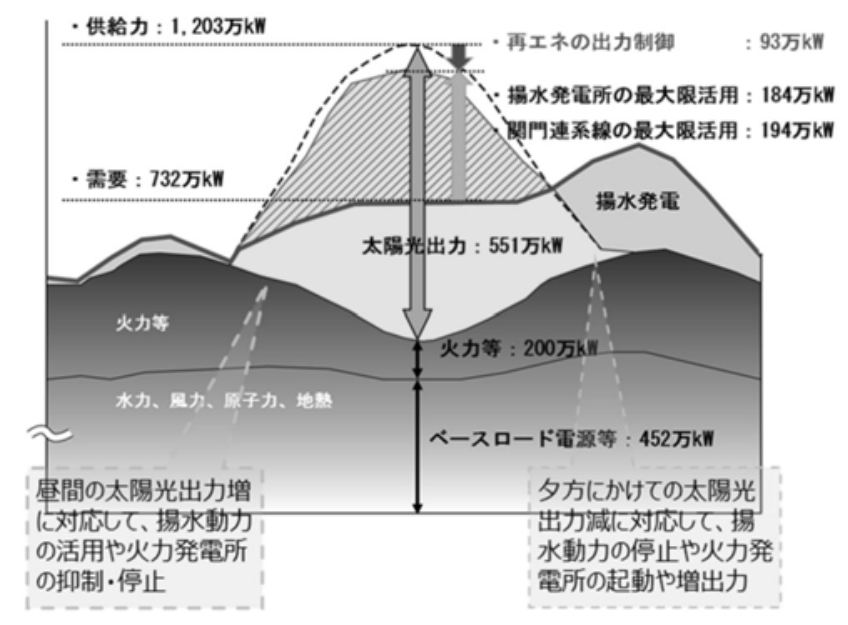

Fig. 2 The demand and supply operation on October 21, 2018 at Kyusyu $\mathrm{EPCO}^{4}$.
導入する必要がある。わが国では電力需要は夏と冬に大き いが、太陽光発電電力は春と秋に出力が大きく冬には小さ い。このため、太陽光発電が大量に導入された電力システ ムでは発電と需要のアンバランス分を季節間で貯蔵し活用 する必要があると言われている。貯蔵以外の対策としては 太陽光発電が余剩になる場合は Fig. 2 のように太陽光発電 からの出力を抑制する方法、あるいは電力が余剰になった 場合は水素あるいはアンモニアなどのカーボンフリー燃料 製造に電力を使う方法もある。我が国で 2050 年を想定し ているカーボンニュートラル社会でどのような季節間の発 電と電力需要のアンバランス解消法が技術的、経済的に優 れているかはまだ十分には検討が進んでいないのが現状で ある。

再生可能エネルギーが大量に導入された電力システム運 用のもう一つの検討事項は、再生可能エネルギーが豊富に 賦存する地域と電力需要が大きい地域が離れていることで ある。特に風力発電の適地は北海道および東北地方北部と 九州地域であり、いずれの大電力消費地からも離れており 長距離送電線が必要になる。ただし、世界的には送電距離 $2000 \mathrm{~km}$ を越える直流送電線は既に複数運転されており新 規の技術開発が必要になるわけではない6)。

電力システムの運用との視点からは、 $\mathrm{kWh}$ で示される エネルギーの需要と供給の整合に加え $\mathrm{kW}$ で示される瞬時 瞬時のパワーの需要と供給の整合も重要である。 $\mathrm{kW}$ の整 合が取れないと周波数の下降あるいは上昇が生じ、発電機 が電力系統から切り離されることによる大停電の発生の可 能性が高まる。この瞬時瞬時の $\mathrm{kW}$ の整合を取るために は $\Delta \mathrm{kW}$ で示される発電出力あるいは負荷の大きさの調整 能力が重要になる。さらに、 $\mathrm{kW}$ の不整合により発生する 周波数変化の時定数を長くするために、同期発電機あるい は同期調相機などが有している慣性力も一定程度必要であ る。最近、この慣性力をインバーター電源の出力制御によ り疑似的に付与寸る研究も進められているが、同期機が有 する慣性力を完全に置き換えることは、インバーター電源 の出力電流制限の影響、過酷事故時の運転継続性、制御方 式によっては制御の遅れの等のため、現状では課題がある と考えられる 7)。再生可能エネルギーなど非同期電源の導 入量 $75 \%$ を目指しているアイルランドの電力系統におい ても、大規模電源脱落時の周波数低下速度を制限するため に、最大需要の 8 割程度に相当する同期発電機を電力系統 に連系をしながら系統運用を行っている ${ }^{8)}$ 。

\section{4. 超電導技術への期待}

2050 年に我が国でカーボンニュートラル社会を実現す るための電力システムの姿はまだ明確ではないが、これか ら研究開発が進められる新しい技術を含め、超電導技術な どあらゆる技術を総動員する必要があることは間違いない。 
この中で特に超電導技術に期待される役割は下記の通りで ある。

\section{1 電力の大量輸送技術としての超電導技術}

我が国で再生可能エネルギーを大量に利用する際には、 電力の長距離送電技術は不可欠である。ただし、例えば稚 内駅から東京駅までの直線距離は約 $1100 \mathrm{~km}$ であり、世界 的な長距離送電線の長さとの比較においては既存技術で対 応可能である。現時点ではまだ具体的検討が始まってはい ないが北海道から本州に送電する場合に、敷設ルートの自 由度が高い直流海底ケーブルを利用することも有力視され ている。直流ケーブルは超電導の特性を最も発揮しやすい 超電導電力機器である。既に架空送電技術として実用化さ れている直流送電技術である $\pm 800 \mathrm{kV}$ の送電電圧で 1000 万 $\mathrm{kW}$ の電力を送電する場合、ケーブル導体の電流值 は $6250 \mathrm{~A}$ であり外部からの侵入熱を想定しても超電導化 による低損失化が十分に期待できる電流容量である。直流 超電導ケーブルを適用する場合は、送電電圧を下げ送電電 流值を上げる方がより適切と想定されるが、最適化のため には詳細な設計研究が必要である。

これまでの我が国における電力システム構築の考え方で は、1 回線の送電線で 1000 万 $\mathrm{kW}$ を送電すると送電線が 故障した場合の電力システムへの影響が大きく大規模停電 を引き起こしかねないため、このような送電線計画は無 かった。しかし、カーボンニュートラルは大規模停電の発 生リスクと比較衡量すべき重要な政策目標であると考えら れ、大規模停電発生リスクへの対応が可能であれば導入の 可能性は高い。

\section{2 電力の需給調整技術としての超電導技術}

前述の通り、出力が大きく変動する再生可能エネルギー を大量に導入した電力系統では電力需給の $\mathrm{kW}$ の整合を取 る技術も重要である。発電電力を増やすために LNG コン バインド発電所を起動する、電力需要を増やすために水素 を製造する水の電気分解装置を立ち上げることなどが想定 されるが、再生可能エネルギーの変動の速さと発電あるい は需要創造の立ち上げの速さが整合しないことが予想され る。LNG コンバインド発電では電池貯蔵装置を併設する ことにより見かけの立ち上げスピードを速める研究開発も 進められている。このような電力貯蔵装置では、貯蔵電力 量よりも発電時あるいは貯蔵時の $\mathrm{kW}$ の大きさが重要であ り、これまでの SMES 研究の成果から見ると経済的にも最 も SMES の特徴を発揮しやすい適用先である。

送電電力が大きく変化する場合は、電力系統各点の電圧 を適正に保つために有効電力だけではなく無効電力の調整 も重要である。超電導同期発電機あるいは超電導同期調相 機は、同期リアクタンスが小さいため進み無効電力範囲を 含め無効電力の調整範囲が広く、無効電力の調整装置とし ては極めて高性能である。さらに、同期機であるため電力 系統の慣性力を確保できるとのメリットもある。電力系統
の慣性力を高めるために再生可能エネルギーのインバー ター出力を電動機に入力し同期発電機から出力する $\mathrm{M}-\mathrm{G}$ セットを介して電力系統に接続するとの考え方も提案され ており 9)、この M-G セットの同期発電機を超電導化するこ とも一つの考え方である。今後の更なる検討を期待したい。

\section{3 電カシステムのフレキシビリティを高める 超電導技術}

再生可能エネルギーを電力システムに大量に導入するた めには、世界的にも電力システムのフレキシビリティを高 めることが重要であると言われている 10)。電力システム の状況は電源種別の割合および電力系統構成を含めて国に より大きく異なり、我が国の場合にフレキシビリティの範 疇に何が含まれるかはまだ検討の途上であるが、研究開発 が進められている超電導電力機器の立場から見ると以下の 適用法が有望である。

(1) SMES による電力系統の安定度評価と安定度対策

電力システムでは想定される落雷などによる送電線の短 絡事故等が起こっても継続的に安定に送電を継続できるこ とをすべて確認した上で運転が行われている。再生可能エ ネルギーによる発電が大量に導入された電力系統では、電 源と負荷のバランスと空閒的配置が時々刻々変化するため、 事前の電力系統安定度評価がすべての事象をカバーできて いない可能性もある。このような事態に備えて、電力系統 の安定度を SMESにより電力系統振動の固有值としてリア ルタイムで計測することが提案されている ${ }^{11) 。 さ ら に 、 ~}$ SMES をそのまま電力系統安定化装置として利用すること も可能である。SMES は大きな電力 $\mathrm{kW}$ を短時間電力シス テムに注入する装置としては理想的な特徴を有しており、 更なる検討が期待される。

海外の例ではあるが、米国では風力発電などの再生可能 エネルギーが大量導入された場合の電力系統の安定度評価 も進められている 12)。米国西海岸を含むWECC(Western Electricity Coordinating Council)電力系統では、 $\mathrm{kWh}$ ベース で風力発電が $20 \%$ 導入された場合、従来発電機 $48.49 \mathrm{GW}$ 、 風力発電機 $13.5 \mathrm{GW}$ として Los Angeles 近郊で 10 秒間の 3 相短絡事故を仮定すると、 $0.6540 \mathrm{~Hz}$ と $0.8121 \mathrm{~Hz}$ の電力潮 流振動が発生するとしている。この検討では風力発電機群 で WADC (wide-area damping controller)を作動させることに より振動減衰を早めることが出来るとしているが、SMES によっても同様な振動減衰が可能である。

(2) 超電導ケーブルによる送電ルートのフレキシビリ ティ向上

超電導ケーブルは導体断面での電流密度が銅などの導体 と比較すると数十倍高く、その分単位送電電力当たりの重 量が軽い。このため、ケーブル敷設時の重量支持構造が簡 略化でき、これまで電力ケーブルの敷設が困難であったと ころへの敷設も可能となる。これは、電源あるいは大容量 負荷の立地制約を緩めることが出来る可能性があり、個別 
地点ごとの検討とはなるが有望な適用法となる見込みが高 い。

また、洋上風力発電の設置方式として浮体式の基礎上へ の設置技術の開発が進められている。浮体式の場合、風力 発電からの出力は電力ケーブルを通じて陸上に送電される が、着床式と異なりライザーケーブルと言われる海中に浮 遊する電力ケーブルを用いて浮体から海底まで接続する。 このライザーケーブルの適用事例は世界的に見てもまだ多 くはないが、今後、電力ケーブル自体の軽量化が開発課題 となる可能性もある。その場合、超電導ケーブルの軽量性 が課題解決につながる可能性もある。

(3) 超電導限流器による短絡電流抑制技術

既存の電力系統に新規の電源を接続する際には接続後の 電力系統の短絡事故時の短絡電流が遮断器の性能で決まる 規定值を上回らないことを毎回確認している。上回る場合 は、電源からの送電線を伸ばし電源の接続点を短絡電流が 問題とならない点に移す、電力系統の短絡電流の規定值を 引き上げ、関係する遮断器を更新し定格を上げるなどの方 策がとられる。新規電源の接続点に超電導限流器を設置す ることにより、接続後の短絡電流を従来の規定值以下に保 つことが出来れば、その費用対効果は上記の従来対策技術 との比較において極めて高いことが予想される。個別の事 案ごとの検討が必要ではあるが、有望な適用法となる見込 みが高い。

(4) 超電導同期機による無効電力制御

超電導発電機あるいは超電導調相機の無効電力制御能力 は制御範囲、界磁の励磁電流に対する応答性など、界磁磁 束密度が高いことによる低同期リアクタンス設計が可能な ことから、従来の同期発電機、同期調相機と比較して本質 的に優れている。特に、電機子巻線に鉄心を持たないた め、従来機に存在する電機子巻線の鉄心端部の過熱による 進相無効電力の制限がないことから進相の無効電力の運転 範囲が広くなり、電力系統全体の電圧が上昇する傾向があ る再生可能エネルギーが大量に導入された電力システムに おいては、電圧上昇を抑制できる進相運転範囲が広い超電 導同期機の必要性が高まることが予想される。

\section{5. おわりに}

電力システム改革は、一部の市場がまだ開設されていな いなどの点は残るものの、発送電分離などの大きな制度改 革はほぼ終了している。今後は 2021 年 1 月に発生した卸 電力市場の予想を上回る高騰をどのように回避するかなど の微調整が進められるものと予想される。一方、2050 年 カーボンニュートラル社会を目指して電力システムがどの ように貢献できるかは、まだ検討が始まったばかりであり、 今後の研究開発が必要となる技術的課題も十分には整理さ
れていない。いずれにしても、我が国の限られた国土で カーボンニュートラル社会を実現する技術的ハードルは他 国と比較して極めて高く、超電導を含むあらゆる技術を総 動員する必要があることは間違いない。低温工学および超 電導技術が貢献できる技術的課題も多くあり、継続的に技 術開発の状況を注視し、低温工学・超電導学会として積極 的に情報を発信していくことが重要である。

\section{参 考 文 献}

1) 服部徹：「電力システム改革における新市場創設の意義と課 題」, 電力経済研究 66 (2019) 1-16

2) 電力中央研究所研究資料 NO. Y 19501，2050 年の $\mathrm{CO}_{2}$ 大規模 削減を実現するための経済およびエネルギー・電力需給の定 量分析（2019年 4 月）, https://criepi.denken.or.jp/jp/serc/source /pdf/Y19501.pdf（参照 2021-6-9）

3）経済産業省：グリーンイノベーション基金事業の基本方針, 令和 3 年 3 月, https://www.meti.go.jp/press/2020/03/20210312003 /20210312003-1.pdf（参照 2021-6-9）

4) 国立研究開発法人 新エネルギー産業技術総合開発機構：グ リーンイノベーション基金事業ホームページ，https://www. nedo.go.jp/activities/green-innovation.html（参照 2021-6-9）

5) 資源エネルギー庁：2050 年カーボンニュートラルの実現に 向けた検討, (2020年12月 21 日), https://www.enecho.meti.go. jp/committee/council/basic_policy_subcommittee/035/035_004.pdf (参照 2021-6-9)

6) 国立研究開発法人 新エネルギー産業技術総合開発機構 北 京事務所 : 中国のスマートグリッドと超高圧送電網の状況, 2020 年 5 月, https://www.nedo.go.jp/content/100918711.pdf（参 照 2021-6-9)

7) 天野博之: 周波数面から見た現状と課題, 令和 2 年電気学会 全国大会 H1-2，2020 年 3 月

8) EIRGRID : Operational Constraints Update http://www.eirgridgroup.com/site-files/library/EirGrid/Operational_ Constraints_Update_May_2021.pdf (参照 2021-6-9)

9) 北内義弘、青木廉：再生可能エネルギーと蓄電池を伴う M-G セットの提案, 平成 30 年電気学会電力・エネルギー部門大 会, $168(2018)$

10) System Integration of Renewables (IEA Insight Series 2018) https://www.nedo.go.jp/content/100879811.pdf（参照 2021-6-9）

11) S. Nomura, T. Nitta and T. Shintomi: "Mobile superconducting magnetic energy storage for on-site estimations of electric power system stability", IEEE TRANS. APPL. SUPERCOND. 30 (2020) 5700207

12) F. Li, K. Tomsovic and H. Cui: "A large-scale testbed as a virtual power grid,” IEEE Power \& Energy 18 No.2 (2020) 60-68

秋 田調 1954 年 8 月 20 日生。1977 年東京大学工学部電 気工学科卒業。1979 年同大学院工学系研究科修士課程（電気工学 専攻）修了。1979 年電力中央研究所入所。主に超電導電力機器の 研究開発に従事。低温工学・超電導学会, 電気学会, IEEE 会員。 博士 (工学)。 